\title{
Karyotype Analysis in Three New Species of Echeandia (Liliaceae) and Cytotypes of E. reflexa
}

\author{
Javier Martínez and Guadalupe Palomino \\ Laboratorio de Citogenética, Jardín Botánico, Instituto de Biología, Apartado Postal 70-614, \\ Universidad Nacional Autónoma de México, D.F. 04510, México
}

Accepted April 10, 1996

In a previous paper we (Palomino and Martínez 1994) reported different cytotypes in three diploid populations $(2 \mathrm{n}=16)$ of Echeandia analyzed: E. echeandioides, E. tenuis and $E$. mexicana. Cytotype variation was observed in heteromorphic pairs of metacentric, submetacentric and subtelocentric chromosomes, and in chromosomes with satellite. Meiotic analysis showed spontaneous heterozygotic exchanges. Metaphase I (MI) analysis showed heteromorphic bivalents (IIs) and quadrivalents (IVs). Analysis of anaphase I (AI) displayed U-type chromatid exchange and subchromatid aberrations (SAB).

This report details karyotypes, meiotic chromosome behavior and pollen fertility of four additional Mexican species of the genus: Echeandia hintonii, E. montealbanensis, E. pubescens, and three cytotypes of $E$. reflexa.

\section{Material and methods}

Plant material. The species studied were: Echeandia hintonii Cruden, distributed in Guerrero State (Cruden 1993), E. montealbanensis Cruden, considered to be endemic to the Monte Albán area in Oaxaca State (Cruden 1993), E. pubescens Cruden, distributed in México State (R. W. Cruden, personal communication); and E. reflexa Cruden (=Anthericum reflexum (Cav.) Rose, which is distributed in the mountains from Texas to Chiapas, one of the diversification centers for species of the genus (R. W. Cruden, personal communication).

Plant material was collected from wild populations in pine-oak forests (Appendix 1). Voucher specimens were deposited at the National Herbarium of the Universidad Nacional Autónoma de México (MEXU).

For each species, three to six individual plants were collected from one or three populations. Plants were taken to the Jardín Botánico of the Universidad Nacional Autónoma de México, where they were transplanted into pots containing a mixture of vermiculite and organic soil, and maintained in a greenhouse.

Mitotic and meiotic chromosome analyses. The cytological methods for the analysis of mitotic chromosomes, types of bivalents in MI, abnormalities in AI, and pollen grain fertility, are detailed in Palomino and Martínez (1994).

For karyotype and total haploid chromatin length (TCL) analysis, we observed 9 cells of three to six plants for each population. For MI analysis, 168 pollen mother cells (PMCs) were analyzed for each population. For AI analysis we recorded 1179 to 1422 PMCs. To estimate pollen fertility, 692 to 874 pollen grains were analyzed for each population.

Data analysis. Differences between fourteen genotypes of seven species of Echeandia were analyzed based on the data published by us (Palomino and Martínez 1994), and on the results reported here. Inter and intraspecific variation of total haploid chromatin length was determined for fourteen populations of Echeandia using analysis of variance (ANOVA); means were compared using Tukey's method. The relation between unviable pollen grain number and 
presence of anaphase irregularities was determined for fourteen populations of seven species of Echeandia using both Pearson's correlation analysis and regression analysis. Unviable pollen percentage was transformed to probit units, and percentage of irregularities during anaphase was transformed using the logarithm of probit units (Fisher and Yates 1963). Statistical analysis was performed in the computer using Statgraphics 4.0 software.

\section{Results}

Samples from the single population studied of each $E$. hintonii, E. montealbanensis and $E$. pubescens, as well as those collected from three population of $E$. reflexa, were diploid with $2 \mathrm{n}=$

Table 1. Karyotypes of Echeandia hintonii, E. montealbanensis, E. pubescens and cytotypes of E. reflexa

\begin{tabular}{|c|c|c|c|c|c|c|c|}
\hline \multirow{2}{*}{$\begin{array}{l}\text { Species and populations } \\
\text { E. hintonii } 308\end{array}$} & \multirow{2}{*}{$\begin{array}{l}\text { Karyotypes } \\
10 m+6 s m\end{array}$} & \multirow{2}{*}{$\begin{array}{c}\begin{array}{c}\text { Secondary } \\
\text { constrictions }\end{array} \\
4 \mathrm{~m}\end{array}$} & \multirow{2}{*}{$\begin{array}{c}\begin{array}{c}\text { Range of } \\
\text { chromosome } \\
\text { length }(\mu \mathrm{m})\end{array} \\
1.73-3.47\end{array}$} & \multicolumn{2}{|c|}{$\begin{array}{l}\text { Total haploid } \\
\text { chromatin } \\
\text { length }(\mu \mathrm{m}) \\
\bar{\chi} \pm \mathrm{EE}\end{array}$} & \multicolumn{2}{|c|}{$\begin{array}{c}\mathrm{TF}(\%) \\
\bar{\chi} \pm \mathrm{EE}\end{array}$} \\
\hline & & & & 22.99 & 0.30 & 38.97 & 0.01 \\
\hline E. montealbanensis 4015 & $8 m+6 s m+2 s t$ & $4 \mathrm{~m}$ & $1.74-5.65$ & 28.68 & 0.04 & 35.85 & 0.01 \\
\hline E. pubescens 482 & $\begin{array}{l}6 \mathrm{~m}+8 \mathrm{sm}+2 \mathrm{st} \\
\text { Cytotypes }\end{array}$ & $4 \mathrm{sm}$ & $3.47-8.70$ & 48.70 & 0.43 & 35.71 & 0.01 \\
\hline E. reflexa 260 & $4 m+8 s m+4 s t$ & $2 m+2 s t$ & $2.16-4.78$ & 27.37 & 0.26 & 33.32 & 0.01 \\
\hline E. reflexa 290 & $8 m+8 s m$ & $4 \mathrm{~m}$ & $1.74-3.90$ & 22.15 & 0.04 & 37.25 & 0.01 \\
\hline E. reflexa 292 & $8 m+6 s m+2 s t$ & $2 m+2 s t$ & $4.34-8.69$ & 48.66 & 0.30 & 34.64 & 0.01 \\
\hline
\end{tabular}

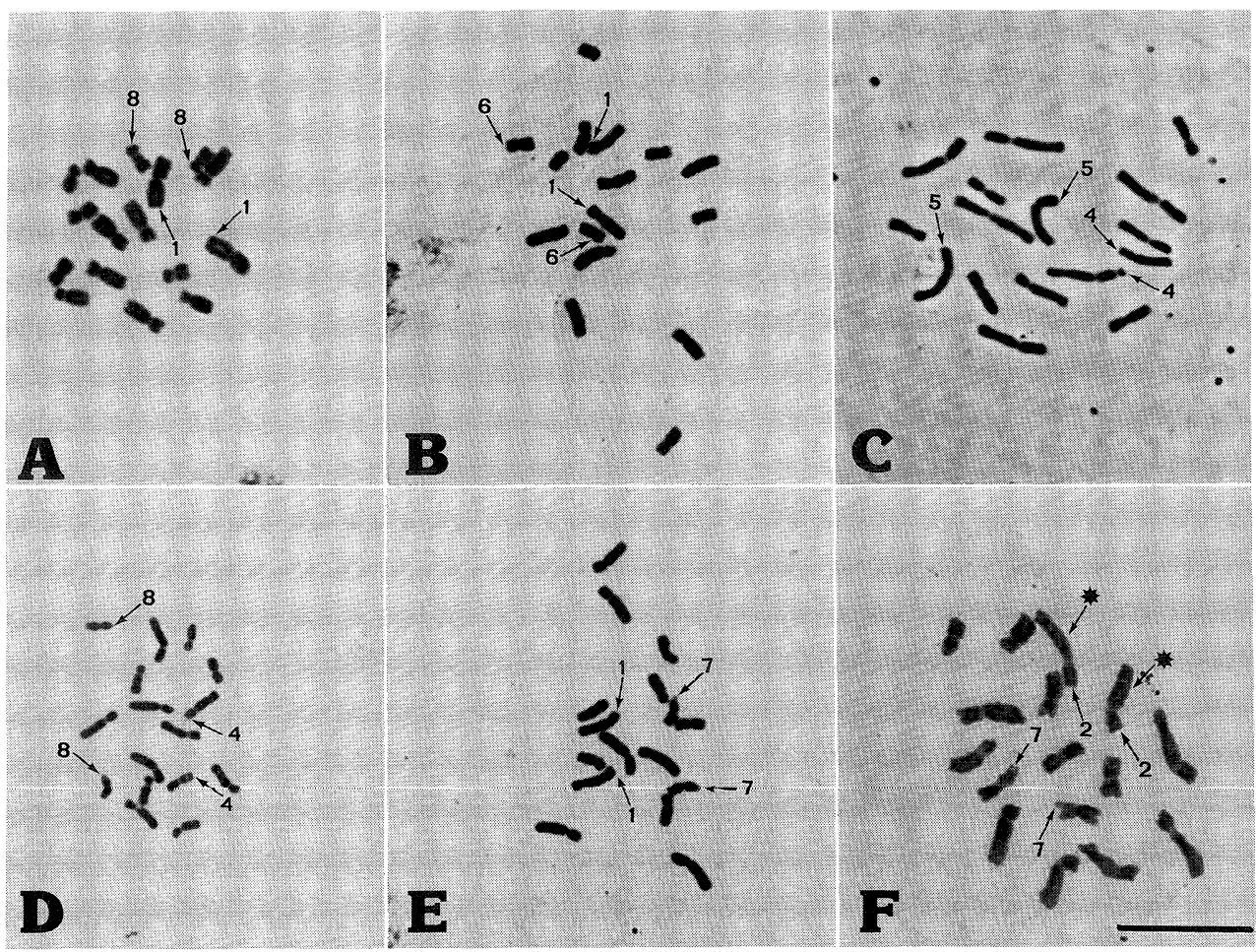

Fig. 1. Karyotypes of: (A) Echeandia hintonii (308), (B) E. montealbanensis (4015), (C) E. pubescens (482), and of cytotypes: (D) Echeandia reflexa (260), (E) E. reflexa (290), and (F) E. reflexa (292). Numbers indicate chromosomes with satellites. Asterisk indicates pair of heteromorphic chromosomes. Scale equals $10 \mu \mathrm{m}$. 
16 and $n=8$. Each species had a different karyotype (Table 1, Figs. 1,2) with different numbers of metacentric, submetacentric and subtelocentric chromosome pairs. All of them presented two pairs of chromosomes with satellite. Each population of E. reflexa had a different cytotype, which was uniform within populations (Table 1). Cytotype of E. reflexa sample no. 292 showed one pair of heteromorphic chromosomes in mitosis (Figs. 1, 2F). Meiotic behavior of the six population of four species of Echeandia sampled was studied by determination of the average number of chiasmata per cell, and by calculation of the recombination index. Ring and rod bivalents at MI were found with variable frequencies (Table 2). Both in Echeandia hintonii and in E. montealbanensis all bivalents were homomorphic. Echeandia pubescens showed three heteromorphic bivalents. Cytotypes of E. reflexa Nos. 260 and 290 had 2 heteromorphic bivalents, while cytotype No. 292 showed four of these (Table 4).

All population studied exhibited variable frequencies of aberrations at AI (Table 3). Echeandia hintonii, E. montealbanensis, E. pubescens and the three cytotypes of E. reflexa had cells with one or two bridges, (subchromatid aberrations, side arm bridges or SAB), and cells with bridges with a fragment (U-type chromatid exchange). In addition, cytotypes of Echeandia reflexa and $E$. pubescens showed lagging chromosomes (Table 3). Compared to $E$. hintonii and $E$. montealbanensis, $E$. pubescens and the three cytotypes of $E$. reflexa displayed more structural chromosomal aberrations, and more non-viable pollen grains (Table 3 ).

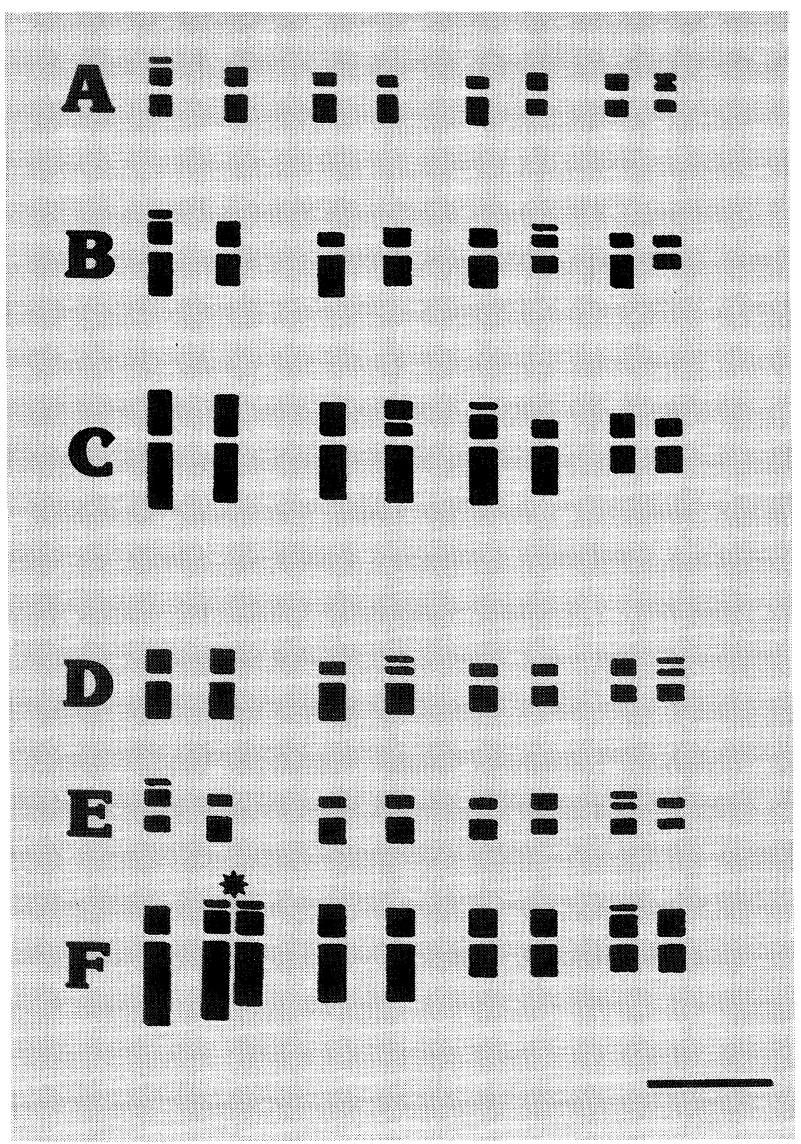

Fig. 2. Idiograms of: (A) Echeandia hintonii (308), (B) E. montealbanensis (4015), (C) E. pubescens (482), and of cytotypes: (D) E. reflexa (260), (E) E. reflexa (290), and (F) E. reflexa

(292). Asterisk indicates pair of heteromorphic chromosomes. Scale equals $10 \mu \mathrm{m}$. 
Table 2. Type and frequency of bivalents (IIs), chiasmata frequency and recombination index (RI) for Echeandia hintonii, E. montealbanensis, E. pubescens and cytotypes of E. reflexa

\begin{tabular}{|c|c|c|c|c|c|c|c|c|c|}
\hline \multirow{2}{*}{$\begin{array}{l}\text { Species and populations } \\
\text { E. hintonii } 308\end{array}$} & \multirow{2}{*}{$\begin{array}{c}\text { No. of } \\
\text { PMCs }\end{array}$} & \multicolumn{2}{|c|}{$\begin{array}{l}\text { Ring IIs } \\
\bar{\chi} \pm \mathrm{EE}\end{array}$} & \multicolumn{2}{|c|}{$\begin{array}{l}\text { Rod IIs } \\
\bar{\chi} \pm \mathrm{EE}\end{array}$} & \multicolumn{2}{|c|}{$\begin{array}{c}\text { Chiasmata per cells } \\
\bar{\chi} \pm \mathrm{EE}\end{array}$} & \multicolumn{2}{|c|}{$\begin{array}{c}\mathrm{RI} \\
\bar{\chi} \pm \mathrm{EE}\end{array}$} \\
\hline & & 5.66 & 0.09 & 2.34 & 0.09 & 13.66 & 0.73 & 21.66 & 0.07 \\
\hline E. montealbanensis 4015 & 168 & 4.98 & 0.15 & 3.02 & 0.15 & 12.07 & 0.86 & 20.07 & 0.01 \\
\hline E. pubescens 482 & 168 & 5.05 & 0.15 & 2.90 & 0.15 & 13.06 & 0.13 & 21.06 & 0.01 \\
\hline E. reflexa 260 & 168 & 5.15 & 0.15 & 2.90 & 0.15 & 13.15 & 0.21 & 21.15 & 0.03 \\
\hline E. reflexa 290 & 168 & 4.67 & 0.17 & 3.33 & 0.17 & 12.67 & 0.27 & 20.67 & 0.02 \\
\hline E. reflexa 292 & 168 & 5.02 & 0.10 & 2.98 & 0.10 & 13.02 & 0.08 & 21.02 & 0.04 \\
\hline
\end{tabular}

Table 3. Shrunken or empty pollen grains and irregular A1 for Echeandia hintonii, E. montealbanensis, $E$. pubescens and cytotypes of E. reflexa

\begin{tabular}{|c|c|c|c|c|c|c|c|}
\hline Species and populations & $\begin{array}{l}\text { Shrunken or } \\
\text { empty pollen } \\
\text { grain } \\
\%\end{array}$ & $\begin{array}{l}\text { No. of } \\
\text { PMCs }\end{array}$ & $\begin{array}{c}\text { Irregular } \\
\text { A1 } \\
\text { cells } \\
\%\end{array}$ & $\begin{array}{c}\text { Cells with one } \\
\text { bridge and } \\
\text { fragment } \\
\%\end{array}$ & $\begin{array}{l}\text { Cells with } \\
\text { one } \\
\text { bridge } \\
\%\end{array}$ & $\begin{array}{c}\text { Cells with } \\
\text { two } \\
\text { bridges } \\
\%\end{array}$ & $\begin{array}{c}\text { Cells with } \\
\text { lagging } \\
\text { chromosomes } \\
\%\end{array}$ \\
\hline E. hintonii 308 & 5.70 & 1099 & 5.83 & 0.18 & 5.10 & 0.55 & \\
\hline E. montealbanensis 4015 & 3.61 & 1244 & 4.66 & & 4.42 & 0.24 & \\
\hline E. pubescens 482 & 22.54 & 1422 & 22.36 & 3.31 & 12.73 & 5.34 & 0.98 \\
\hline E. reflexa 260 & 13.64 & 1184 & 15.62 & 2.45 & 9.29 & 3.46 & 0.42 \\
\hline E. reflexa 290 & 16.52 & 1179 & 17.98 & 3.14 & 10.43 & 3.82 & 0.59 \\
\hline E. reflexa 292 & 18.31 & 1384 & 21.53 & 3.18 & 12.57 & 4.99 & 0.79 \\
\hline
\end{tabular}

\section{Discussion}

All populations of the four species examined were diploid with $2 n=16$, and $n=8$. These results agree with reports from other authors for 23 species of Echeandia (Schnarf and Wunderlich 1939, Palomino and Romo 1987, Cruden 1987, 1993, 1994, Cruden and McVaugh 1989, Palomino and Martínez 1994). Given this, and chromosome numbers for 16 polyploid species of the genus (4x, 5x, 6x, 8x, 10x and 11x-4) (Palomino and Romo 1987, Cruden 1981, 1986, 1993, 1994), we agree with Palomino and Romo (1987) in considering Echeandia as a monobasic genus with $\mathrm{X}=8$.

Echeandia hintonii, E. montealbanensis, E. pubescens and E. reflexa, had distinctive karyotypes. All three populations of E. reflexa analyzed displayed intraspecific cytotype variation.

High frequency of heteromorphic bivalents in MI was observed in the eleven populations of the five species and cytotypes of Echeandia studied (Table 4). Some cytotypes had three or four heteromorphic bivalents (Echeandia echeandioides Nos. 359 and 360, E. tenuis No. 484, and $E$. reflexa No. 292), most of the cytotypes showed two of these (Echeandia mexicana Nos. 357 and 284, E. reflexa Nos. 260 and 290, and E. tenuis No. 356), and cytotypes of Echeandia echeandioides Nos. 359 and 360 presented heteromorphic quadrivalents (Table 4).

Heteromorphic bivalents and quadrivalents reflect heterozygotic exchanges, as demonstrated in several species of the tribe Aloineae by Brandham (1973, 1974, 1976), and by Brandham and Johnson (1977). Kenton et al. (1987) and Kenton and Drakeford (1990) have reported heterozygotic exchanges in Gibasis pulchella, and in Tradescantia cymbispatha (Commelinaceae), respectively.

Heteromorphic IIs in mitosis were absent from E. mexicana Nos. 284 and 357, E. reflexa Nos. 260 and 290, and E. pubescens (Table 4), which may be due to one of the following causes: 1. - translocation was of a very small size, or 2.-translocation was equal for both chromo- 
Table 4. Heteromorphic chromosome pairs, and heteromorphic bivalents (IIs), and quadrivalents (IVs) of seven species of Echeandia

\begin{tabular}{|c|c|c|c|}
\hline \multirow{2}{*}{ Species and cytotypes } & \multirow{2}{*}{$\begin{array}{l}\text { Heteromorphic } \\
\text { chromosome pairs }\end{array}$} & \multicolumn{2}{|c|}{ Heteromorphic } \\
\hline & & IIs & IVs \\
\hline${ }^{*}$ E. echeandioides 359 & 3 & 3 & 2 \\
\hline${ }^{*}$ E. echeandioides 360 & 1 & 3 & 1 \\
\hline${ }^{*} E$. echeandioides 321 & & 1 & \\
\hline \multicolumn{4}{|l|}{ E. hintonii 308} \\
\hline \multicolumn{4}{|l|}{ *E. mexicana 236} \\
\hline *E. mexicana 284 & & 2 & \\
\hline *E. mexicana 357 & & 2 & \\
\hline \multicolumn{4}{|l|}{ E. montealbanensis 4015} \\
\hline E. pubescens 482 & & 3 & \\
\hline E. reflexa 260 & & 2 & \\
\hline E. reflexa 290 & & 2 & \\
\hline E. reflexa 292 & 1 & 4 & \\
\hline${ }^{*}$ E. tenuis 356 & 1 & 2 & \\
\hline${ }^{*}$ E. tenuis 484 & 2 & 3 & \\
\hline
\end{tabular}

* Reported by Palomino and Martínez (1994).

somes in which rearrangement took place.

Additional evidence for translocations and chromatid exchange is found in the low level of meiotic irregularities observed during AI, including U-type bridges associated with an acentric fragment, SAB without acentric fragments, and lagging chromosomes. Samples analyzed of Echeandia hintonii, E. montealbanensis, E. pubescens and cytotypes of E. reflexa (Table 3), as well as cytotypes of $E$. echeandioides, E. tenuis and E. mexicana (Palomino and Martínez 1994), showed 1 or 2 SAB in variable proportion, and more frequently than U-type chromatid exchanges, the latter were absent from $E$. montealbanensis. These U-type chromatid exchanges were observed in 186 plants belonging to 167 taxa in the tribe Aloineae, in proportions ranging from 1 to $20 \%$. In $22 \%$ of these plants, U-type exchange occurred alone, and chromatid and subchromatid aberrations (SAB) occurred together in $56 \%$ of them. No plants produced subchromatid errors alone (Brandham 1970).

Heteromorphic bivalents and bridges with or without fragment reflect structural changes such as heterozygous inversions, Robertsonian translocations, exchanges, deletions and duplications (Brandham 1970, Brandham and Johnson 1977, Kenton et al. 1987, Kenton and Drakeford 1990, Palomino and Vázquez 1991, Palomino and Martínez 1994).

Total chromatin length (TCL), or genome size, of 14 populations of the seven species of Echeandia analyzed both in this paper and in Palomino and Martínez (1994), showed significant inter and intraspecific variation (at $\mathbf{P}<0.01$ level) (Table 5). This fact corroborates the distinctiveness of the cytotypes of $E$. echeandioides, $E$. tenuis and E. reflexa. Intraspecific variation was evident in $E$. echeandioides cytotype No. 359, having a TCL of $53.24 \mu \mathrm{m}$, which is equivalent to more than twice the genome size of cytotype No. 321 ( TCL $=22.98 \mu \mathrm{m})$. A similar case was observed in cytotype No. 292 of E. reflexa $(\mathrm{TCL}=48.66 \mu \mathrm{m})$, having a genome size of more than twice that of cytotype No. $290(\mathrm{TCL}=22.15 \mu \mathrm{m})$ (Table 5).

In some cases, interspecific variation was demonstrated, such as in E. pubescens with TCL of $48.70 \mu \mathrm{m}$, which is more than twice that observed in $E$. hintonii (TCL $=22.90 \mu \mathrm{m}$ ) (Table 5).

Despite that a better estimate of the genome size of species (Price 1988) and of cytotypes (Price et al. 1981a, b, Kenton 1983) is obtained by the amount of DNA in picograms (which is done through scanning spectroscopic measurement of the light absorbency of Feulgen stained nuclei), the variation in the TCL of some cytotypes of Echeandia echeandioides, E. tenuis and 
Table 5. Results of Tukey's multiple range test on mean total haploid chromatin length (TCL) of seven species of Echeandia

\begin{tabular}{|c|c|c|c|}
\hline \multirow{2}{*}{$\begin{array}{l}\text { Species and populations } \\
{ }^{*} \text { E. echeandioides } 359\end{array}$} & \multicolumn{2}{|c|}{$\begin{array}{c}\mathrm{TCL}(\mu \mathrm{m}) \\
\bar{\chi} \pm \mathrm{EE}\end{array}$} & \multirow{2}{*}{$\begin{array}{c}\text { Tukey's grouping } \\
\text { a }\end{array}$} \\
\hline & 53.24 & 0.30 & \\
\hline E. pubescens 482 & 48.70 & 0.43 & $\mathrm{~b}$ \\
\hline E. reflexa 292 & 48.66 & 0.30 & $\mathrm{~b}$ \\
\hline *E. echeandioides 360 & 41.70 & 0.01 & $\mathrm{c}$ \\
\hline${ }^{*}$ E. tenuis 484 & 37.56 & 0.06 & $\mathrm{~d} \mid$ \\
\hline *E. mexicana 236 & 34.73 & 0.02 & e \\
\hline${ }^{*} E$. mexicana 284 & 33.93 & 0.08 & e \\
\hline *E. mexicana 357 & 30.97 & 0.04 & $\mathbf{f} \mid$ \\
\hline${ }^{*}$ E. tenuis 356 & 28.78 & 0.28 & $\mathrm{~g}$ \\
\hline E. montealbanensis 4015 & 28.68 & 0.04 & $\mathrm{~g}$ \\
\hline E. reflexa 260 & 27.37 & 0.26 & $\mathrm{~g}$ \\
\hline E. hintonii 308 & 22.99 & 0.30 & $\mathrm{~h}$ \\
\hline *E. echeandioides 321 & 22.98 & 0.04 & $\mathrm{~h}$ \\
\hline E. reflexa 290 & 22.15 & 0.04 & $\mathrm{~h}$ \\
\hline
\end{tabular}

Lines indicate species that were not significantly different using $\alpha=0.01$. * Reported by Palomino and Martínez (1994).

E. reflexa is evident (Table 5).

The estimation of DNA content often provides a distinctive parameter of species differentiation (Bennett and Smith 1976, 1991), any many examples are reported where differences within species are comparable, or even greater, than differences between species. Intraspecific variation in DNA content of 25\% and 20\% has been reported in Microseris bigelovii (Price et al. 1981a) and in M. douglasii (Price et al. 1981b). Cavallini et al. (1986), found 58.16\% variation of DNA content among cultivars of Helianthus annuus. Variation in DNA content between plants of the same species and the same ploidy level are due to the generation, dispersion and deletion of repeated sequences in there genome (Price 1991). This variation has an effect on several cell attributes, such as the chromosome size, the nuclear and cell volumes, and the length of the mitotic and meiotic cycles, the nucleotypic effect (Bennett 1972, Price 1988). The study of inter and intraspecific DNA content variation patterns, suggest that these variations have an adaptive value, in response to environmental changes, and that they are a subject of natural selection (Price 1991).

Kenton (1983), found 60\% variation in DNA content of 13 diploid cytotypes $(2 n=12)$ of Gibasis venustula subsp. venustula. She also noticed that these changes in DNA content have an adaptive nature, given that DNA content increase was reflected on the different ecological conditions in which the cytotypes live, as well as on their phenotypes (flower color and size, and leaf dimensions). These cytotypes had heteromorphic IIs (during MI), and bridges and fragments (during AI), both of which resulted in heterocygotic inversions. Those cytotypes showing greater values of TCL (genome size), Echeandia echeandioides Nos. 359 and 360, E. tenuis No. 484, E. reflexa No. 292, y E. pubescens 482, were also those displaying larger numbers of structural modifications in their chromosomes (Palomino and Martínez 1994, results in this paper. See Tables 3, 4, 5 and 6). Morphologic variation, such as that observed in Gibasis venustula subsp. venustula cytotypes (Kenton 1983), was not seen in Echeandia cytotypes.

In cytotypes of E. reflexa Nos. 260, 290 and 292, and of E. pubescens abnormal segregation of a lagging chromosome was observed. These same observation was made by Palomino and Martínez (1994) in two cytotypes of E. echeandioides and of E. tenuis. Lagging chromosomes are rarely observed in nature and have been recorded in the meiotic anaphase of pollen grains 
Table 6. Shrunken or empty pollen gains and irregular A1 of seven species of Echeandia

\begin{tabular}{|c|c|c|c|c|}
\hline Species and populations & $\begin{array}{l}\text { No. of pollen } \\
\text { grains }\end{array}$ & $\begin{array}{c}\text { Shrunken or empty } \\
\text { pollen grains } \\
\%\end{array}$ & $\begin{array}{c}\text { No. of PMCs } \\
\text { A1 }\end{array}$ & $\begin{array}{c}\text { Irregular A1 } \\
\%\end{array}$ \\
\hline${ }^{*}$ E. echeandioides 359 & 644 & 29.85 & 998 & 21.44 \\
\hline${ }^{*} E$. echeandioides 360 & 589 & 20.37 & 913 & 17.63 \\
\hline${ }^{*} E$. echeandioides 321 & 238 & 2.94 & 989 & 6.57 \\
\hline E. hintonii 308 & 824 & 5.70 & 1099 & 5.83 \\
\hline *E. mexicana 236 & 633 & 13.74 & 996 & 3.31 \\
\hline${ }^{*}$ E. mexicana 284 & 877 & 2.28 & 678 & 18.10 \\
\hline${ }^{*}$ E. mexicana 357 & 502 & 14.14 & 969 & 14.14 \\
\hline E. montealbanensis 4015 & 692 & 3.61 & 1244 & 4.66 \\
\hline E. pubescens 482 & 865 & 22.54 & 1422 & 22.36 \\
\hline E. reflexa 260 & 726 & 13.64 & 1184 & 15.62 \\
\hline E. reflexa 290 & 817 & 16.52 & 1179 & 17.98 \\
\hline E. reflexa 292 & 874 & 18.31 & 1384 & 21.53 \\
\hline${ }^{*}$ E. tenuis 356 & 361 & 13.85 & 923 & 11.71 \\
\hline${ }^{*}$ E. tenuis 484 & 538 & 23.23 & 994 & 23.14 \\
\hline
\end{tabular}

* Reported by Palomino and Martínez (1994).

from diploid clones coming from several populations of Tradescantia commelinoides (Kenton et al. 1988). Johnson (1980), reported lagging chromosomes, bridges and fragments during AI and AII in polyploid species of Mammillaria prolifera, these aberrations resulted in abnormal segregation and, thus, in pollen grains of reduced size and in an increase in the proportion of unviable pollen.

Those 14 populations from 7 species of Echeandia showing larger numbers of both chromatid exchanges and heterocygotic inversions, also had larger proportion of unviable pollen $(\mathrm{r}=0.80)$ (Table 6). These unviable pollen grains were derived from chromatid exchanges, inversions, and lagging chromosomes. In Gibasis pulchella, diploid plants being heterocygotic for a chromatid exchange also had an increased proportion of unviable pollen (Kenton et al. 1987). The presence of the same cytotype in different populations of Echeandia species suggests, these were originated from a single plant by vegetative reproduction, which is common among the species of the genus. It can be assumed that several aberrant cytotypes confer advantages to those individuals carrying them in the colonization of new habitats.

In sum, chromosomal rearrangements may have played an important role in the evolution of Echeandia. The occurrence of these chromosomal aberrations has a common behavior pattern in species and cytotypes of Echeandia. Observation of bivalents and of low frequency of quadrivalents and bridges, both with and without fragments, as well as the presence of heteromorphic chromosome pairs, suggests that translocations and chromatid exchange have played a major role in shaping the karyotypes of populations and species.

\section{Summary}

Karyotypic analysis of Echeandia hintonii, E. montealbanensis, E. pubescens and three populations of $E$. reflexa, showed that all of them were diploid with $2 \mathrm{n}=16, \mathrm{n}=8$ and $\mathrm{X}=8$. Each species had a distinctive karyotype. Also, each one of the populations of Echeandia reflexa analyzed presented a distinct karyotype. Cytotype variation was observed in heteromorphic chromosome pairs. Meiotic analysis showed heteromorphic exchanges. Analysis of MI showed heteromorphic IIs, while AI analysis showed U-type chromatid exchanges and subchromatid aberrations. Lagging chromosomes were recorded in AI of E. pubescens and in cytotypes of $E$. reflexa. Those cytotypes with a larger proportion of chromosomal aberrations, 
were also those with greater proportion of unviable pollen and a larger value of TCL (genome size). Based on these results and on previous reports, we can suggest that translocations and chromatid exchange, follow a behavior pattern common to species and cytotypes of Echeandia, and that these chromosome aberations have played a major role in the evolution of the genus, providing with a larger potential for colonization and distribution in new habitats.

\section{Appendix 1}

E. hintonii. Guerrero state, $4 \mathrm{Km}$. from the deviation to Agua de Obispo, Palomino and Martínez 308 (MEXU).

E. montealbanensis. Oaxaca state, Monte Albán, Abisaí García 4015 (MEXU).

E. pubescens. México state, $4 \mathrm{Km}$. from Temascaltepec towards Valle de Bravo, Javier Martínez 482 (MEXU).

E. reflexa. 1. Hidalgo state, $8 \mathrm{Km}$. from Jacala towards Zimapán, Palomino and Martínez 260 (MEXU). 2. Hidalgo state, $3 \mathrm{Km}$. from Molango towards Zacualtipán, Palomino and Martínez 290 (MEXU). 3. México state, $13.5 \mathrm{Km}$. Molango to Zacualtipán, Palomino and Martínez 292 (MEXU).

\section{Acknowledgments}

This study was supported by OEA: "Estudios Biosistemáticos en algunos géneros de Leguminosas, Liliaceae y Palmas de México": Citogenética 88-89, PRDCyT, CONACyT and Jardín Botánico of the Instituto de Biología of the Universidad Nacional Autónoma de México. We are grateful to Dr. Robert Cruden for the identification names of the plants used in this research and to Rocío Cid for her help in editing the tables.

\section{References}

Bennett, M. D. 1972. Nuclear DNA content and minimum generation time in herbaceous plants. Proc. R. Soc. Lond. B 181: 109-135.

- and Smith J. B. 1976. Nuclear DNA amounts in angiosperms. Phil. Trans. R. Soc. Lond. B 274: $227-274$.

— and Smith J. B. 1991. Nuclear DNA amounts in angiosperms. Phil. Trans. R. Soc. Lond. B 334: $309-345$.

Brandham, P. E. 1970. Chromosome behaviour in the Aloineae III. Correlations between spontaneous chromatid and sub-chromatid aberrations. Chromosoma (Berl.) 31: 1-17.

- 1973. The chromosomes of the Liliaceae III: new cases of interchange hybridity in the Aloineae. Kew Bull. 28: 341348.

- 1974. Interchange and inversion polymorphism among population of Haworthia reinwardtii var. chalummensis. Chromosoma (Berl.) 47: 85-108.

- 1976. The frequency of spontaneous structural change. In: K. Jones and P. E. Brandham, (eds.). Current Chromosome Research, 77-87. Amesterdam, Elsevier North Holland Biomedical Press.

- and Johnson, M. A. T. 1977. Population cytology of structural and numerical chromosome variants in the Aloineae (Liliaceae). Plant Syst. Evol. 128: 105-122.

Cavallini, A., Zolfino, C., Cionini, G., Cremonini, R., Natali, L., Sassoli, O. and Cionini, P. G. 1986. Nuclear DNA changes within Helianthus annuus L. cytophotometric, Karyological and biochemical analyses. Theor. Appl. Genet. 73: 20-26.

Cruden, R. W. 1981. New Echeandia (Liliaceae) from México. Sida 9: 139-146.

- 1986. New species of Echeandia (Liliaceae) from Central America. Phytologia 59(6): 373-380.

- 1987. New species of Echeandia (Liliaceae) from Nueva Galicia. Contr. Univ. Mich. Herb. 16: 129-133.

- 1993. New species of Echeandia (Liliaceae) from Oaxaca, México. Phytologia 74(2): 128-137.

- 1994. 3. Echeandia Ortega. In: G. Davidse, M. S. Sousa y A. O. Charter, (eds.), Flora Mesoamericana, Alismataceae a Cyperaceae, vol. 6, 27-30. México, Universidad Nacional Autónoma de México, Instituto de Biología.

— and McVaugh, R. 1989. Echeandia Ortega. In: W. R. Anderson, (ed.). Flora Novo-Galiciana, Bromeliaceae to 
Dioscoreaceae, vol. 15, 178-197. USA, The University of Michigan Herbarium Ann. Arbor.

Fisher, R. A. and Yates, F. 1963. Statistical Tables for Biological, Agricultural and Medical Research, 6th ed. Oliver and Boys, Edinburgh. 10-73.

Johnson, M. A. T. 1980. Further cytological investigations in Mammllaria prolifera and other Mammillaria species. Cact. Succ. J. Gr. Brit. 42(2): 43-47.

Kenton, A. 1983. Qualitative and quantitative chromosome change in the evolution of Gibasis. In: Proceedings of the Seconds Chromosome Conference held in Jodrell Laboratory, Royal Botanic Gardens, Kew England, 1-4 September 1982. P. E. Brandham and M. D. Bennett (eds.). G. Allen and Unwin, 273-281.

-, Davies, A. and Jones, K. 1987. Identification of Renner complexes and duplications in permanent hybrids of Gibasis pulchella (Commelinaceae). Chromosome (Berl.) 95: 424-434.

-, Langton, D. and Coleman, J. 1988. Genomic instability in a clonal species, Tradescantia commelinoides (Commelinaceae). Genome 30: 734-744.

- and Drakeford, A. 1990. Genome size and karyotype evolution in Tradescantia section Cymbispatha (Commelinaceae). Genome 33: 604-610.

Palomino, G. and Romo, V. 1987. Karyotypic studies in two Mexican species of Echeandia Ort. (Liliaceae). The Southwestern Nat. 33: 382-384.

- and Vázquez, R. 1991. Cytogenetic studies in Mexican population of species of Crotalaria L. (LeguminosaePapilionoideae). Cytologia 56: 343-351.

- and Martínez, J. 1994. Cytotypes and meiotic behavior in Mexican populations of three species of Echeandia (Liliaceae). Cytologia 59: 295-304.

Price, H. J., Chambers, K. L. and Bachmann, K. 1981a. Genome size variation in diploid Microseris bigelovii (Asteraceae). Bot. Gaz. 142(1): 156-159.

- Chambers, K. L., and Bachmann, K. 1981b. Geographic and ecological distribution of genomic DNA content variation in Microseris douglasii (Asteraceae). Bot. Gaz. 142(3): 415-426.

- 1988. DNA content variation among higher plants. Ann. Missouri Bot. Gard. 75: 1248-1257.

- 1991. Genomic stress, genome size, and plant adaptation. In: Ecological genetics and air pollutions. G. E. Taylor, Jr., L. F. Pitelka and M. T. Clegg (eds.) Spring-Verlag. 277-287.

Schnarf, K. and Wunderlich, R. 1939. Zur vergleichenden embryologie der Liliaceae-Asphodelideae. Flora 133: 297327. 